EESTI NSV TEADUSTE AKADEEMIA TOIMETISED 1954. III kd., nr. 2 ИЗВЕСТИЯ АКАДЕМИИ НАУК ЭСТОНСКОИ ССР 1954. ТОМ III, № 2

\title{
KASULIKE MULLA MIKROORGANISMIDE ARENGU SOODUSTAMINE KULVISEEMNE TOOOOTLEMISE ABIL MIKROELEMENTIDE JA TEISTE STIMULEERIVATE AINETEGA
}

\author{
P. RAHNO, \\ bioloogiateaduste kandidaat
}

Mulla viljakus on lahutamatult seotud mulla mikroorganismide tegevusega ning seetõttu on mulla viljakuse tõstmiseks väga oluline aktiivselt mõjutada mulla mikrofloora koosseisu ja arengut. Selle teostamiseks on mitu võimalust.

Kõigepealt mõjutab mulla mikroorganismide arengut rida üldagrotehnilisi vôtteid: harimine, väetamine, melioratsioonitööd, külvikordade rakendamine jm. Eriti suurt tähelepanu mulla mikroorganismide arengu ja tegevuse soodustamisele osutatakse akadeemik V. R. Viljamsi maaviljeluse heinaväljasüsteemis. Eeskujuliku agrotehnika kasutamine on mulla mikroorganismide tegevuse suunamisel asendamatu ning on vältimatuks eeltingimuseks ka kõigi teiste samale eesmärgile suunatud spetsiaalsete abinõude edukuseks.

Spetsiaalabinõudest on NSV Liidus eriti viimasel ajal levinud bakterväetiste kasutamine. Oma ettekandes NLKP Keskkomitee septembripleenumil märgib seltsimees N. S. Hruštšov vajadust laialdasemalt kasutada bakterväetisi.

Uks levinenum bakterväetiste liik, mis eriti Eesti NSV muldadel on paljudel juhtudel häid tulemusi andnud, on azotogeen (mulla preparaat), või azotobakteriin (azotobakteri puhaskultuur). Azotogeeni mõju põhjeneb ühe mulla mikroorganismi 2 azotobakteri tegevusel. Preparaadis on azotobakteri hulk tôstetud võimaliku maksimumini (200 miljonit rakukest ühes azotogeeni grammis, värskes preparaadis tihti tunduvalt rohkem).

Azotobakter on üks tähtsam õhulämmastikku koguv mikroorganism ning seetõttu mõjub azotogeen peamiselt lämmastikväetisena, kuigi teatud tähtsust omab ka azotobakteri võime nn.. kasvuaineid moodustada.

Azotobakteri väetispreparaadid võimaldavad suuri saagitõuse ainult kõrge agrotehnika rakendamisel ja ainult muldadel, mis kõigiti azotobakteri rõuetele vastavad. Sellistes muldades esineb aga alati küllalt suur hulk looduslikku azotobakterit. Eesti NSV Teaduste Akadeemia Taimekasvatuse Instituudi poolt viimastel aastatel korraldatud katsed tõestavad, et azotobakteri väetispreparaadid on efektiivsed ainult muldadel, kus esineb looduslik azotobakter. Seega preparaatide mõju ei seisne azotobakterivaba mulla rikastamises azotobakteriga, vaid-selle mikroorganismi mulda viimisega külviseemne välispinnal mõjutatakse mullas leiduva azotobakteri 
intensiivset paljunemist seemnest areneva juurekava lähemas ümbruses või nn. risosfääris. Mikroorganismide mulda viimist teostatakse peamiselt kevadel, mil mulla mikrofloora ja eriti azotobakter on alles tegevusse astumise staadiumis.

Kui aga arvesse võtta, et azotogeeni tarvitamine on efektiivne ainult sellistel muldadel, milledes esineb looduslik azotobakter, tekib küsimus, kas ei ole võimalik teistest muldadest väljaeraldatud azotobakteri muldaviimise asemel püüda looduslikku azotobakterit koguda muldakülvatud seemnete pinnale. Sellisel korral meie ei eralda azotobakterit mullast mitte kunstlikes laboratooriumi tingimustes katseklaasidesse, et teda hiljem uuesti teises kohas seemnetega mulda viia, vaid taotleme tema kolooniate moodustamist vahetult seemnete pinnal, ilma et muid ümbruskonna tingimusi muudetaks.

Selleks on tarvis luua azotobakteri jaoks eriti soodsad elutingimused väljakülvatud seemnete pinnal enesel ja seemnete lähimas ümbruses. Seda on võimalik teha seemnete külvieelse töötlemise abil azotobakteri elutegevust soodustavate ainetega. Peale azotobakteri võib selliste ainetega töötlemine soodustada ka mitmesuguste teiste azotobakterile lähedaste mulla mikroorganismide arengut, nagu anaeroobne õhulämmastiku fikseerija Clostridium Pasteurianum, nitrifitseerijad ja veel mõni bakterirühm.

Seemnete külvieelse töötlemisega mitmesuguste ainetega tegelesid taimefüsioloogid juba mõnikümmend aastat tagasi $\left({ }^{6}\right)$. Eriline huvi selle küsimuse vastu tekkis peale $M$. Popoffi tööde avaldamist $\left({ }^{26},{ }^{27}\right)$. Mitmesuguste kemikaalidega seemneid töödeldes sai Popoff suuri saagitõuse kuni 50 ja isegi $100 \%$. Sellist efekti põhjendas ta nn. „rakustimulatsiooni” teooriaga, mille kohaselt töötlemine pidi ergutama seemne rakkusid intensiivsemale tegevusele, mis omakorda pidi põhjustama kiiremat kasvu ja arengut. Kui aga tema põldkatseid kordasid teised uurijad - ja muidugi teistel muldadel - ei leidnud Popoffi andmed kinnitust. Mõnede katsetega ei saadud mingisuguseid saagitõuse, teistel juhtudel saadi ainult vähe enamsaake $\left({ }^{7},{ }^{24}\right)$. Seetõttu vaibus huvi küsimuse vastu ning vaid üksikud uurijad jätkasid katsetamist seemnete töötlemisega.

Popoff kasutas seemnete töötlemiseks mitmesuguseid aineid, näiteks magneesiumi ja mangaani ühendite lahuseid, samuti ka mõningate orgaaniliste ühendite (tanniini) lahuseid.

M. J. Školniki $\left({ }^{18}\right)$, P. A. Vlasjuki ja M. M. Skvaruki $\left({ }^{4}\right)$, A. Z. Lambini $\left({ }^{8}, 9\right)$, D. I. Gobelevi $\left({ }^{5}\right)$ ja teiste uurimised tõendavad, et seemnete külvieelne töötlemine võimaldab viljasaakide tõuse, kuigi tulemused on küllaltki lahkuminevad. Nimetatud uurijad kasutasid seemnete töötlemiseks mitmesuguste mikroelementide, nagu boori, mangaani, molübdeeni, tsingi jt. ühendite lahuseid. Skolnik märgib, et ,,seemnete külvieelne töötlemine muutub väga perspektiivseks, kui 1 äh e b korda täpsusta da t ing i musi, millede juures. seemnete töötlemine efekti a n n a b".

Teatavasti avaldavad mikroelemendid soodustavat mõju mitte ainult kõrgemate taimede, vaid ka mikroorganismide kasvule. Paljude uurijate töödes märgitakse mikroelementide sellist mõju azotobakteri arengule ja elutegevusele. H. Bortels $(19,20,21,22)$ peab azotobakteri elutegevuse jaoks tähtsaimaks mikroelemendiks molübdeeni, märkides, et vanaadium ja volfram avaldavad samasugust mõju ning võivad molübdeeni asendada. Bortels leiab, et kui kaltsium on vajalik kõikidele organismidele, siis molübdeen omab samasugust tähtsust lämmastikku koguvate mikroorganismide jaoks. Samuti rõhutavad molübdeeni tähtsust azotobakterile C. B. Van-Niel $\left({ }^{28}\right)$, D. Burk ja C. Horner $\left({ }^{23}\right)$ ning rida teisi autoreid $\left(12,{ }^{15}\right)$.

Kui molübdeeni stimuleeriva mõju suhtes azotobakterile erinevaid arva- 
musi ei esine, siis boori ja mangaani suhtes lähevad üksikute autorite arvamused lahku. F. Herzniger $\left({ }^{25}\right)$ kinnitab, et isegi võrdlemisi suured boorikogused mõjuvad azotobakterile, samuti Clostridium Pasteurianum'ile ja möningatele vetikatele hästi. S. I. Matuašvili $\left({ }^{10,}{ }^{11}\right)$ leiab, et boor ei ole azotobakterile vajalik mikroelement, küll aga mangaan, mille väiksemad kogused stimuleerivad azotobakteri elutegevust, kuna suuremad kogused algul pidurdavad seda ja hakkavad positiivset mõju avaldama alles teatud aja möödumisel. M. V. Fjodorov $\left({ }^{16},{ }^{17}\right)$, tõendades molübdeeni ja boori stimuleerivat mõju azotobakterile, peab mangaani (samuti ka rauda ja alumiiniumi) ōhulämmastiku sidumist pidurdavaks teguriks.

Hoolimata lahkarvamustest üksikute mikroelementide mõju suhtes peab enamik uurijaid nii molübdeeni kui ka mangaani ja boori azotobakteri elutegevuse stimuleerijateks. Vastavalt sellele tuleb pidada tõenäoliseks, et mitte ainult see osa mikroelementidest, mis seemnete külvieelse töötlemise puhul imendub seemnerakkudesse, vaid ka see, hulgalt nähtavasti tunduvalt suurem osa, mis pärast mikroelementide lahuses esineva vee aurumist jääb seemnete välispinnale, võib mõju avaldada saakide tõusule mulla mikroorganismide tegevuse stimuleerimise kaudu. Ei saa isegi eitada võimalust, et just see osa etendab viljasaakide tõstmisel peamist osa. Pärast töödeldud seemnete mulda sattumist tekivad nende ümber erilised tsoonid, milledes ōhulämmastikku koguvate mikroorganismide elutegevus on soodustatud. Kui mullas esineb looduslik azotobakter, areneb ta eriti hästi nendes tsoonides lähemal või kaugemal seemnete välispinnast, olenevalt seemnete pinnal mulda viidud mikroelementide kogustest.

Mikroelementide mõju taimekasvule peab järelikult olema suurem sellistes muldades, milledes esineb looduslik azotobakter. Sama kehtib muidugi ka seemnete teiste ainetega töötlemise mõju kohta.

Viimasel ajal on NSV Liidu paljudes rajoonides üsna laialdaselt levinud N. Mokini $\left(13,14,{ }^{2}\right)$ poolt välja töötatud ,seemnete rikastamise" meetod seemnete töötlemine linnasejahu leotisega. Mokin põhjendab oma meetodit seemnete rikastamisega lisatoitainete ja fermentidega. Terade linnasteks kasvatamisel muutuvad nendes esinevad varuained - tärklis, rasvad ja valgud - fermentatiivsete protsesside toimel veeslahustuvateks süsivesikuteks ja lämmastikuühenditeks. Seemnete töötlemisel nende ainete vesileotisega imevad seemned paisudes oma rakkudesse vees lahustunud toitaineid ja kasutavad neid edaspidi kasvuprotsessis. Mokini andmete järgi võib selline seemnete lisaainetega rikastamine põhjustada 10 -11-tsentnerisi saagitõuse hektari kohta.

Seemnete töötlemine Mokini meetodi järgi on andnud häid tulemusi ka Eesti NSV sovhoosides ( ${ }^{1}$ ).

Vaidlemata Mokini meetodi võimaliku efektiivsuse vastu, ei saa nõustuda tema teoreetiliste pōhjendustega. Isegi eitamata lisatoitainete seemnetesse imendumise võimalusi, on väga raske ette kujutada, et selline mehaaniline ,rikastamine” võib esile kutsuda suuri saagitõuse. Varutoitainete mõju võib avalduda idu kiiremas arengus, kuid juurekava moodustumise momendist alates toimub taime toitumine juba juurte kaudu mullast saadavate toitainete arvel, nende kättesaadavaks muutmisel aga etendavad erakordselt tähtsat osa mulla mikroorganismid.

Seemnete töötlemine linnaseleotisega ei erine põhiliselt millegagi seemnete töötlemisest teiste azotobakteri elutegevust soodustavate ainetega. Valdav osa selliseid aineid, keskmiselt $85-95 \%$, ei imendu seemnerakkudesse, vaid jääb seemne välispinnale. Siin on aga nende mõju suunatud mitte taime füsioloogiliste protsesside mõjutamisele, vaid esmajoones mulla mikroorganismide tegevuse, eriti õhulämmastikku koguvate bakterite tegevuse tõstmisele $\left({ }^{3}\right)$. 
Käsitledes seemnete töötlemise mõju ja selle mõju pōhjusi sellelt seisukohalt, mis oluliselt erineb seni levinud seisukohtadest, millede järgi töötlemise mõju oleneb ainuüksi taime füsioloogilisi protsesse mõjutavatest keemilistest teguritest, pole liigne märkida, et kuni viimase ajani rakendatakse bioloogiliste küsimuste uurimisel dialektilise meetodi põhimõtteid alles puudulikult. Kuigi on selge, et mingi küsimuse uurimisel, mis kuulub teatud loodusliku nähtuse keerukasse kompleksi, metoodilised kaalutlused sunnivad meid seda küsimust üldkompleksist eraldama ning seda eraldi uurima, pole siiski lubatav tegelda ainuüksi meid huvitava küsimusega, unustades, et „looduses ei saa mõista ainsatki nähtust, kui võtta seda isoleerituna, ümbritsevate nähtustega seostamata, sest iga nähtuse igas looduse valdkonnas võib muuta mõttetuseks, kui vaadelda seda ümbritsevate tingimustega seostamata, neist lahus, ja, vastupidi, iga nähtust võib mõista ning pōhjendada, kui seda vaadeldakse selle lahutamatus seoses ümbritsevate nähtustega, selle tingituses seda ümbritsevaist nähtustest". *

Käesoleval juhul on meil tegemist kahe küsimusega, mis ei näi pealiskaudsel vaatlemisel omavat midagi ühist: küsimus ôhulämmastikku siduvate bakterite tegevusest mullas ning taimede risosfääris ja küsimus seemnete külvieelse töötlemise mõjust taime füsioloogilistele protsessidele. Kuid mõlema küsimuse vahel esineb tõenäoliselt vägagi tihe seos. Seni tegelesid esimese küsimusega ainult mikrobioloogid ning teisega peamiselt taimefüsioloogid. Tulevikus tuleb aga mõlema küsimuse põhjalikumaks lahendamiseks rakendada mitme eriala uurijate kollektiivset tööd.

Seemnete mitmesuguste ainetega töötlemise mõju on uuritud Eesti NSV Teaduste Akadeemia Taimekasvatuse Instituudi Kuusiku filiaali katsepõldudel korraldatud katsetega alates 1946. aastast. Kõik need katsed toimusid neutraalsetel kamar-karbonaatsetel muldadel, kus alati esines looduslik azotobakter. Kogu katsealale anti ühtlane fosfori-kaaliumi mineraalväetis, tavaliselt $200 \mathrm{~kg}$ superfosfaati ja $100 \mathrm{~kg} \mathrm{40 \% -list} \mathrm{kaalisoola} \mathrm{(või} \mathrm{vastav}$ kogus kloorkaaliumi) ha kohta. Orgaanilisi väetisi enamike katsete puhul, mis suviteraviljadega korraldati, ei tarvitatud, mineraallämmastikväetisi samuti mitte, välja arvatud katsed, kus poolele katseala kõikidest variantidest anti tugev lämmastikväetis, pool aga jäeti võrdluseks ilma lämmastikväetiseta.

Esimene orienteeriv põldkatse rajati 1946. aasta sügisel talirukkiga. Selles katses kasutati seemnete töötlemiseks mikroelemente: molübdeeni ammoonium-molübdaadina $\left(\mathrm{NH}_{4}\right)_{2} \mathrm{MoO}_{4}$, mangaani mangaan-sulfaadina $\left(\mathrm{MnSO}_{4}\right)$ ja boori booraksina $\left(\mathrm{Na}_{2} \mathrm{~B}_{4} \mathrm{O}_{7}\right)$. Mikroelemente kasutati kahesugusel hulgal: $\mathrm{m}$ a d a 1 a t e normidena -2 grammi $3 \mathrm{~kg}$ seemnete kohta ehk 120 grammi ha kohta ja kõ rg ete normidena - 20 grammi $3 \mathrm{~kg}$ seemnete kohta. Esimese normi valikul arvestati mikroelementide môju azotobakterile taimede juurekava ümbruses (risosfääris), kõrge normi puhul aga mõju terves künnikihis. Peale selle kasutati mikroelemente nii üksikult kui ka segudes. Katsed teostati kummagi mikroelementide normiga kaheksas variandis: $\mathrm{Mo}, \mathrm{Mn}, \mathrm{B}, \mathrm{Mo}+\mathrm{Mn}, \mathrm{Mo}+\mathrm{B}, \mathrm{Mn}+\mathrm{B}, \mathrm{Mo}+\mathrm{Mn}+\mathrm{B}$ ja kontroll. Katsed viidi läbi kolmes korduses $25 \mathrm{~m}^{2}$ suurustel katselappidel. Enne külvi, augustikuus, määrati katseala mullas kindlaks azotobakteri sisaldus, mis osutus võrdlemisi kõrgeks: kümnest kuni saja tuhandeni ühe grammi mulla kohta.

Seemnete puhtimiseks kasutati formaliini. Pärast formaliini lendumist töödeldi seemneid mikroelementidega. Et saavutada mikroelementide paremat kinnistumist seemnetele, lahustati nad suhkru kaheprotsendilises vesilahuses. Vett võeti ainult nii palju, kui osutus vajalikuks mikroelementide

* J. Stalin, Leninismi küsimusi, Tallinn, 1952, Ik. 504. 
soolade täielikuks lahustamiseks, arvestamata mikroelementide kontsentratsiooni lahuses, kuna kohe pärast töötlemist lasti vesi täielikult ära aurata. Mikroelemendid jäid seemnete külge.

Külv viidi läbi 30 . augustil ning oras tärkas alates 6 . septembrist, kusjuures selle seisus ja arengus ilmnesid kohe teravad vahed. Enamikul kõrge mikroelementide normiga variantidel jäi oras tunduvalt hõredamaks, eriti variantidel, kus kasutati kõiki kolme mikroelementi. Nähtavasti pidurdas liiga suur mikroelementide kogus seemnete idanevust. Madalate normide puhul arenes oras kõigil variantidel ühesuguselt hästi.

Koristamisel 1947. aasta suvel saadi tabelis 1 toodud keskmised saagid.

Orienteeriv katse näitas küllalt selgelt, et molübdeeni, mangaani ja boori ühendite tarvitamine seemnete töötlemiseks mitte väga suurtes kogustes võib põhjustada saagitõuse $10-20 \%$. Kasutatud mikroelementide normid ei osutunud täiesti optimaalseteks, kuigi madal norm oli nähtavasti lähedasem optimumile. Mikroelementide segud ei andnud paremaid tulemusi kui üksikud mikroelemendid ja edaspidistes katsetes segusid enam ei kasutatud.

Uksikutest mikroelementidest andsid molübdeen ja mangaan peaaegu võrdseid tulemusi, kuna boori mõju jäi kõigis variantides tunduvalt väiksemaks ka madalate normide juures, kõrgete normide puhul aga avaldas boor katsekultuuri arengule selgelt pidurdavat mõju.

Tabel 1

Orienteeriva põldkatse tulemused talirukki seemnete töötlemisel mikroelementidega ENSV TA Taimekasvatuse Instituudi Kuusiku filiaalis 1946/1947 a.

\begin{tabular}{|c|c|c|c|}
\hline \multirow{2}{*}{ Variandid } & \multicolumn{3}{|c|}{$\mathrm{T}$ e $\mathrm{r}$ a s a a $\mathrm{k}$} \\
\hline & ts ha kohta & $\% \%$ & kôikumised \% \\
\hline & \multicolumn{3}{|c|}{$\begin{array}{l}\text { Seemnete töötlemisel mikro- } \\
\text { elementide kôrge normiga }\end{array}$} \\
\hline $\begin{array}{l}\text { Mo } \\
\text { Mn } \\
B \\
\text { Mo }+M n \\
\text { Mo }+B \\
M n+B \\
\text { Mo + Mn }+B \\
\text { Kontroll }\end{array}$ & $\begin{array}{r}20,50 \\
19,64 \\
14,53 \\
19,75 \\
12,07 \\
13,47 \\
4,90 \\
18,81\end{array}$ & $\begin{array}{r}109,0 \\
104,4 \\
77,2 \\
105,0 \\
64,2 \\
71,6 \\
26,0 \\
100,0\end{array}$ & $\begin{array}{r}3,74 \\
2,26 \\
2,33 \\
7,20 \\
11,72 \\
7,57 \\
0,81 \\
4,84\end{array}$ \\
\hline
\end{tabular}

Seemnete töötlemisel mikroelementide madala normiga

\begin{tabular}{l|l|l|l} 
Mo & 17,10 & 121,8 & 7,52 \\
Mn & 16,68 & 118,8 & 3,18 \\
B & 15,64 & 11,4 & 6,29 \\
Mo + Mn & 16,28 & 115,9 & 8,37 \\
Mo + B & 15,36 & 109,4 & 7,39 \\
Mn+B & 15,50 & 110,4 & 3,12 \\
Mo + Mn + B & 15,32 & 109,1 & 8,03 \\
Kontroll & 14,04 & 100,0 & 2,59
\end{tabular}

1947/1948. aasta talvel korraldati ENSV TA Taimekasvatuse Instituudi Kuusiku filiaalis rida laboratoorseid katseid mikroelementide mõju selgitamiseks teravilja seemnete idanevusele. Hiljem on nende katsete tulemusi veel korduvalt kontrollitud. Katsed näitasid, et seemnete töötlemisel mikroelementide soolade lahustega ei avalda seemnete idanevusele mingit mõju lahuste kontsentratsioon, küll aga mikroelementide kogus, mis teatud seemnekoguse kohta võetakse ja mis peale vee aurumist seemnete külge jääb. Seejuures määrati kindlaks mikroelementide maksimaalsed kogused, millised seemnete idanevust veel ei kahjusta. Need olid: 
Mo!übdeeni - $\left(\mathrm{NH}_{4}\right)_{2} \mathrm{MoO}_{4}$ jaoks

Boori $\left(\mathrm{Na}_{2} \mathrm{~B}_{4} \mathrm{O}_{7}\right)$

Mangaani $\left(\mathrm{MnSO}_{4}\right)$

Vanadiumi $\left(\mathrm{NaVO}_{3}\right)$ ja

Volframi $\left(\mathrm{NaWO}_{4}\right)$
$270 \mathrm{~g} 200 \mathrm{~kg}$ seemnete kohta

$270 \mathrm{~g} 200 \mathrm{~kg}$

$530 \mathrm{~g} 200 \mathrm{~kg}$

400 g 200 kg

1948. aastast peale kasutati kõigis põldkatsetes neid norme.

1948. aastal rajati Kuusiku filiaali katsepõllul põldkatse kaeraga $30 \mathrm{~m}^{2}$ suurustel katselappidel, kolmes korduses. Seemnete töötlemine viidi seekord läbi ilma suhkru lisamiseta, mis aga katse tulemusi kahandas. Kui lahusesse ei lisata kleepivaid aineid, siis jäävad mikroelemendid seemnetele püsima väga ebakindlalt. Nende katsete juures, kus kõik külvid teostati reaskülvimasinaga, jäi peale külvi alati masina külge hulk halli tolmu, mis suurelt osalt koosnes seemnete töötlemiseks kasutatud mikroelementide sooladest.

1948. aastast alates püüti katsetega lähemalt selgitada küsimust, kas seemnete töötlemise mõjul saagitõusud olenevad peamiselt taime enese füsioloogiliste protsesside mõjutamisest vọ̃i mulla mikrofloora tegevuse suunamisest. Selle ülesande lahendamisele asuti kahel viisil. Kõigepealt viidi iga katse puhul läbi mikrobioloogiline analüüs, võrreldes azotobakteri, hiljem ka teiste mikroorganismide hulka taimede juurtel ja juurtest kaugemal mullas. Teiseks võrreldi seemnete töötlemise tulemusi kahesugusel lämmastikväetise foonil.

Selleks jaotati katselapid pooleks, kusjuures ühele poolele anti võrdlemisi suur norm mineraal-lämmastikväetist, nimelt $150 \mathrm{~kg}$ ammooniumsalpeetrit ha kohta, kuna teine pool jäeti ilma lämmastikväetiseta. Kui eeldada, et mikroelemendid stimuleerivad peamiselt taime füsioloogilisi protsesse, siis peaks protsentuaalne saagitõus olema ligikaudu ühesugune nii lämmastikväetist saanud poolel kui ka lämmastikväetisega väetamata poolel. Kui aga seemnete töötlemise efekt tuleneb peamiselt õhulämmastikku siduvate mullabakterite tegevuse intensiivistamisest, siis on selge, et protsentuaalne saagitõus peab olema tunduvalt suurem seal, kus mineraal-lämmastikväetist ei kasutatud, sest seal on taime varustamine lämmastikuga täiel määral sõltuv mullabakterite tegevusest.

Selles katses rakendati esmakordselt kaht uut varianti - vanaadiumiga ja porgandimahlaga töötlemist.

Vanaadiumi soodustavat mõju azotobakteri elutegevusele tõendab rida kirjandusandmeid. Porgandimahl võeti tarvitusele kergesti kättesaadava orgaanilise ainena, mida mõnel puhul on suhkru asemel kasutatud nn. mulla azotogeenile lisamiseks. Mahl saadi riivitud porganditest välja pigistades ning seda võeti 10 liitrit ühe ha seemnekoguse kohta.

Lämmastikväetiseta poolelt võeti molübdeeniga variantidelt ja kontrollalalt esimesed mullaproovid azotobakteri hulga määramiseks 13. päeval pärast külvi. Analüüsi andmetel oli siis azotobaktereid ühe grammi mulla kohta kontrollalal 80000 ja molübdeeniga katsealal 110000 .

Umbes kuu aega hiljem - 5. juunil - võeti mõlemalt poolelt uued mullaproovid. Seekord oli azotobakteri hulk tuhandetes ühe grammi mulla kohta:

$\begin{array}{cr}\text { lämmastikväetist saanud poolel } \\ \text { kontrollalal } & -101 \\ \text { molübdeeniga } & -113 \\ \text { ilma lämmastikväetiseta } & \text { poolel } \\ \text { kontrollalal } & -181 \\ \text { molübdeeniga } & -243\end{array}$


Teiste mulla mikroorganismide gruppide kohta tehtud analüüsid ei näidanud kontrollala ja molübdeeniga töödeldud ala vahel suuri erinevusi mikroorganismide hulga suhtes. Mõningad erinevused esinesid aga lämmastikväetisega ja ilma selleta aladelt võetud proovides: lämmastikväetisi saanud mullas oli denitrifitseerivaid baktereid rohkem ja nitrifitseerijaid vähem kui lämmastikväetiseta jäetud mullas.

Koristamisel selgus, et seemnete töötlemisest tingitud saagitõusud ei ulatunud seekord eelmise aasta tasemele. Ainult molübdeeni lämmastikväetiseta variandis ulatus saagitõus 12 protsendini, kuna kõigis teistes variantides oli see väiksem $(4-9 \%)$. Katse tulemuste läbiarutamisel leiti, et peamiseks põhjuseks oli suhkru puudumine lahuses, mistõttu mikroelemendid kergesti seemnete küljest lahti pudenesid. Järgnevates katsetes kasutati jälle suhkru lisamist (2\%-lise lahusena) kõigile variantidele.

1949. aastal korraldati seemnete töötlemisega kaks põldkatset - kaera ja odraga. Mõlemad katsed rajati seitsmes variandis (peale varemalt katsetatavate veel variant volframiga), neljas korduses, $70 \mathrm{~m}^{2}$ suurustel katselappidel, kahesugusel lämmastiku foonil.

Kasvuajal teostatud rida mikrobioloogilisi analüüse andsid eelmise aastaga sarnanevaid tulemusi: kõigil juhtudel oli lämmastiku foonil ja ilma mikroelementideta variantidel azotobakteri hulk madalam kui lämmastikuta foonil ja mikroelementidega töötletud variantidel.

Andmed terasaagi kohta on toodud tabelites 2 ja 3 .

Tabel 2

Saagiandmed kaera pōldkatses seemnete töötlemisel mitmesuguste ainetega 1949. aastal ENSV TA Taimekasvatuse Instituudi Kuusiku filiaalis

\begin{tabular}{|c|c|c|c|c|}
\hline \multirow{2}{*}{ Variandid } & \multicolumn{3}{|c|}{ T e r a s a a k } & \multirow{2}{*}{$\begin{array}{l}\text { Saagitōus } \\
\mathrm{kg} \text { ha kohta }\end{array}$} \\
\hline & ts ha-lt & $\% \%$ & kõikumised \% & \\
\hline & \multicolumn{3}{|c|}{$\begin{array}{l}\text { mine r a a } 1-1 \text { a m mastikug a } \\
(150 \mathrm{~kg} \mathrm{ha-1e)}\end{array}$} & \\
\hline $\begin{array}{l}\text { Kontroll } \\
\text { Mo } \\
\text { Mn } \\
\text { B } \\
\text { V } \\
\text { W } \\
\text { Porgandimahl }\end{array}$ & $\begin{array}{l}30,44 \\
31,71 \\
31,35 \\
30,60 \\
31,52 \\
31,44 \\
30,53\end{array}$ & $\begin{array}{l}100,0 \\
104,2 \\
103,0 \\
100,5 \\
103,5 \\
103,3 \\
100,3\end{array}$ & $\begin{array}{l}1,9 \\
3,2 \\
4,5 \\
3,9 \\
3,4 \\
2,2 \\
3,1\end{array}$ & $\begin{array}{r}127 \\
91 \\
16 \\
108 \\
100 \\
9\end{array}$ \\
\hline & \multicolumn{3}{|c|}{$\mathrm{minera} \mathrm{a} 1-1$ ä m astikuta } & \\
\hline $\begin{array}{l}\text { Kontroll } \\
\text { Mo } \\
\text { Mn } \\
\mathrm{B} \\
\mathrm{V} \\
\text { W } \\
\text { Porgandimahl }\end{array}$ & $\begin{array}{l}14,19 \\
15,58 \\
15,82 \\
15,92 \\
15,49 \\
15,25 \\
16,12\end{array}$ & $\begin{array}{l}100,0 \\
109,8 \\
111,5 \\
112,2 \\
109,2 \\
107,5 \\
113,6\end{array}$ & $\begin{array}{l}8,6 \\
8,9 \\
2,5 \\
3,4 \\
4,9 \\
9,7 \\
8,8\end{array}$ & $\begin{array}{l}\overline{139} \\
163 \\
173 \\
130 \\
106 \\
193\end{array}$ \\
\hline
\end{tabular}

Eriti suured olid odra saagitõusud põldkatsetes lämmastikuta poolel, ulatudes mangaani ja booriga töötlemise puhul ligi 30 protsendini. Need andmed näitavad küllalt veenvalt, et seemnete töötlemise mõju on tihedalt seotud taimede toitmisega lämmastikuga. Vastasel korral oleks arusaamatu, miks seemnete töötlemine lämmastikuta foonil andis tunduvalt suurema efekti kui lämmastikuga väetatud poolel. Kuna aga kõrgemad taimed ise ei ole võimelised õhulämmastiku kasutamiseks, jääb üle vaid seemnete töötlemise stimuleeriv mõju ōhulämmastikku koguvatele bakteritele, osalt 
Saagiandmed odra põldkatses seemnete töötlemisel mitmesuguste ainetega 1949. aastal ENSV TA Taimekasvatuse Instituudi Kuusiku filiaalis

\begin{tabular}{|c|c|c|c|c|}
\hline \multirow{2}{*}{ Variandid } & \multicolumn{3}{|c|}{ Terasa a } & \multirow{2}{*}{$\begin{array}{c}\text { saagitõus kg } \\
\text { ha kohta }\end{array}$} \\
\hline & ts ha-lt & $\% \%$ & kõikumised & \\
\hline - & \multicolumn{3}{|c|}{$\begin{array}{c}\text { mine r a a } 1-1 \text { a m m a s tik ug a } \\
(150 \mathrm{~kg} \mathrm{ha-le)}\end{array}$} & \\
\hline $\begin{array}{l}\text { Kontroll } \\
\text { Mo } \\
\text { Mn } \\
\text { B } \\
\text { V } \\
\text { W } \\
\text { Porgandimahl }\end{array}$ & $\begin{array}{l}25,93 \\
27,51 \\
26,03 \\
27,47 \\
26,57 \\
28,29 \\
26,58\end{array}$ & $\begin{array}{l}100,0 \\
106,1 \\
100,4 \\
105,9 \\
102,5 \\
108,8 \\
102,5\end{array}$ & $\begin{array}{r}4,6 \\
2,2 \\
8,1 \\
2,0 \\
4,1 \\
5,1 \\
11,7\end{array}$ & $\begin{array}{r}\overline{158} \\
10 \\
154 \\
64 \\
227 \\
65\end{array}$ \\
\hline & \multicolumn{3}{|c|}{ minera a $1-1$ äm m stikuta } & \\
\hline $\begin{array}{l}\text { Kontroll } \\
\text { Mo } \\
\text { Mn } \\
\text { B } \\
\text { V } \\
\text { W } \\
\text { Porgandimahl }\end{array}$ & $\begin{array}{l}11,70 \\
14,40 \\
15,09 \\
15,01 \\
12,07 \\
12,66 \\
13,84\end{array}$ & $\begin{array}{l}100,0 \\
123,1 \\
128,9 \\
128,3 \\
103,1 \\
108.2 \\
118,2\end{array}$ & $\begin{array}{r}10,9 \\
9,6 \\
11,5 \\
11,7 \\
7,7 \\
9,8 \\
15,2\end{array}$ & $\begin{array}{r}\overline{270} \\
339 \\
331 \\
37 \\
96 \\
214\end{array}$ \\
\hline
\end{tabular}

vahest ka nitrifitseerijatele. Võrreldes saadud saagiandmeid mikrobioloogilise analüüsi andmetega, võib lugeda tõestatuks, et seemnete töötlemine mõjub mulla mikroorganismide tegevuse tõstmise kaudu. Teisest küljest pole võimalik eitada ka selle võtte otsest mõju taime füsioloogilistele protsessidele, sest ka kõrgel lämmastiku foonil, kus õhulämmastikku koguvate bakterite tegevus vaevalt mingit tähtsust võis omada, saadi siiski alati teatud saagitõus.

Vanaadium ja volfram andsid vaid üsna väikesi enamsaake.

Huvitavad on porgandimahlaga teostatud katsevariandi andmed. Siin pole nähtavasti mingit mõju taime füsioloogilistele protsessidele ja küllalt olulised saagitõusud - 13,6 ja 18,2 protsenti - tuleb tervenisti kanda mulla mikroorganismide tegevuse tõstmise arvele. Nende tulemuste tõttu püüti edaspidistes katsetes seemnete töötlemiseks kasutada rohkem orgaanilisi aineid.

Katsed seemnete töötlemisega andsid 1949. aastal mõnevõrra paremaid tulemusi kui teistel aastatel. Pole kahtlust, et selleks väga olulisel määral kaasa aitasid paremad meteoroloogilised tingimused 1949. aasta kevadsuvel. Märgime, et ka masskatsetes azotogeeniga saadi 1949. aastal paremaid tulemusi kui ühelgi teisel katseaastal.

1950. aastal korraldati seemnete töötlemisega kolm pōldkatset ainuüksi odraga. Uks katse viidi läbi $75 \mathrm{~m}^{2}$ suurustel katselappidel neljas korduses variantidega Mo, Mn, B, V ja kontroll. Teine katse oli rajatud Kuusiku filiaali majapidamispõllul, umbes ühe ha suurustel lappidel, ilma kordusteta, Mo, Mn ja kontrollvariantidega. Kolmandas katses kasutati $50 \mathrm{~m}^{2}$ suuruseid katselappe, neljas korduses ning yariantideks olid linnaseleotis Mokini meetodi järgi, porgandimahl ja kontroll.

1950. aasta väheste sademetega suvi ei pakkunud efektiivsete katsetulemuste saamiseks kuigi häid eeldusi, kuid üldiselt ei jäänud katsetulemused eriti maha samal suvel azotogeeniga korraldatud katsete tulemustest. 
Nagu eelnevatelgi aastatel, viidi ka 1950. aastal kõigi põldkatsete puhul läbi rida mikrobioloogilisi analüüse. Analüüside tulemused näitasid ka seekord seemnete töötlemise soodustavat mõju mulla mikroorganismide, eriti azotobakteri arengule taime risosfääris ja ümbritsevas mullas.

Odrasaagid kontroll-katselappide lämmastikväetiseta aladelt osutusid kõigis katsetes ligikaudu võrdseteks: 14,$46 ; 14,97$ ja 14,70 tsentnerit ha kohta. Saagitõusud mikroelementidega katselappidel olid:-molübdeeniga $13,1 \%$, mangaaniga $10,6 \%$, booriga $9,4 \%$ ja vanaadiumiga $3,4 \%$. Tootmistingimustes läbi viidud katsel: mangaaniga $9,4 \%$ ja molübdeeniga $2,4 \%$. Orgaaniliste ainetega: linnaseleotisega $9,0 \%$ ja porgandimahlaga $4,7 \%$.

1951. aastal korraldati põldkatse ka kartuliga, mis oli puhtmikrobioloogilist laadi - nimelt azotobakteri mitmesuguste tüvede võrdluskatse, millesse võeti juurde veel üks variant - seemnemugulate töötlemine Ashby lahusega.

Ashby lahus on tavaline ja väga levinud sööde azotobakteri kasvatamiseks laboratoorsetes tingimustes. Selle koosseisu kuuluvad kõik azotobakteri elutegevuseks vajalikud keemilised ühendid. Ashby lahust võeti $10 \mathrm{~kg}$ kartulimugulate kohta 200 milliliitrit.

Põldkatse kartuliga viidi läbi $10 \mathrm{~m}$ pikkustel vagudel, viies korduses. Kogu katsealale anti $300 \mathrm{~kg}$ superfosfaati, $150 \mathrm{~kg}$ kaalisoola ja 30 tonni laudaväetist ha kohta. Igas katsevariandis pandi maha kokku 200 mugulat, millede keskmine kaal oli 52 grammi. Kóristamisel saadi kartuleid:

Kontrollalalt $\quad-209,67$ ts ha kohta $=100,0 \%$, keskmine mugula kaal $42,6 \mathrm{~g}$

Kõige paremaks

osutunud azoto-

bakteri tüvega

(kohalik nr. 5) $-272,33$ ts ha kohta $=129,88 \%$, keskmine mugula kaal $51,6 \mathrm{~g}$

Ashby lahusega $-272,33$ ts ha kohta $=129,88 \%$, keskmine mugula kaal $54,8 \mathrm{~g}$

Seega Ashby lahusega töödeldud seemnemugulate saak võrdus täpselt kõige paremaks osutunud kohaliku azotobakteri tüvega rajatud katsevariandi saagiga, ainult mugulaid oli Ashby variandis vähem ja seetõttu keskmine mugula kaal suurem. Tähendatud kartulisaagid olid Kuusiku põldudel 1951. aastal kõige kõrgemad, ületades ka kõrgsaagi katsete saagid, kus kasutati üsna suuri mineraal-lämmastikväetise norme. Teised, samas katses järeleproovitud azotobakteri tüved andsid väiksemaid saagitõuse: 6,99 kuni $29,56 \%$.

Mikrobioloogilised uurimised selle katse juures teostati Holodnõi meetodi järgi, millega aga erilisi vahesid üksikute katsevariantide mikroflooras ei õnnestunud kindlaks teha.

Samal - 1951. aastal korraldati ka põldkatsed odraga, milles esinesid kõik seniste uurimuste põhjal perspektiivsetena esinenud katsevariandid ning lisaks veel kaks uut varianti - Ashby lahuse ning virtsaga. Katsesse võeti ka üks variant azotogeeniga. Kontroll rajati kahekordne: harilike, kuivade seemnetega ja $2 \%$-lise suhkrulahusega töödeldud seemnetega. Katselapid olid $25 \mathrm{~m}^{2}$ suurused, kordusi neli. Katsepõld oli eelmisel aastal saanud orgaanilisi väetisi (sisseküntud mesikas). Mineraalväetistest anti seekord $300 \mathrm{~kg}$ superfosfaati ja $150 \mathrm{~kg}$ kaalisoola ha kohta.

Odraga põldkatsete juures teostati mikrobioloogiline analüüs 23. juulil 7 mikroorganismi grupi kohta. Toome selle analüüsi andmed tab. 4 . 
Keskmıne mikroorganismide hulk tuhandetes ühe grammi risosfääri mulla kohta põldkatses odraga 1951. aastal

Kontroll, harilike seemnetega

Kontroll, suhkrulahuses leotatud seemnetega

Molübdeen

Mangaan

Boor

Porgandimahl

Linnaseleotis

Ashby lahus

Virts

Azotogeen

\begin{tabular}{|c|c|c|c|c|c|c|}
\hline 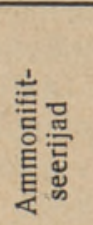 & 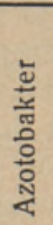 & 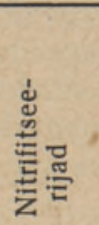 & 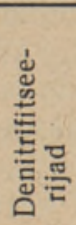 & 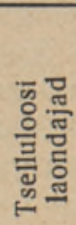 & 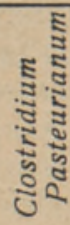 & 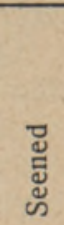 \\
\hline 3500 & 32 & 10 & 10 & 1 & 10 & 265 \\
\hline $\begin{array}{l}3400 \\
3500 \\
3400 \\
2900 \\
3200 \\
3600 \\
3200 \\
3700 \\
3300\end{array}$ & $\begin{array}{l}42 \\
56 \\
56 \\
45 \\
60 \\
54 \\
66 \\
37 \\
45\end{array}$ & $\begin{array}{l}10 \\
12 \\
10 \\
10 \\
10 \\
10 \\
10 \\
10 \\
10\end{array}$ & $\begin{array}{l}10 \\
10 \\
10 \\
10 \\
10 \\
10 \\
10 \\
15 \\
10\end{array}$ & $\begin{array}{l}1 \\
1 \\
1 \\
1 \\
1 \\
1 \\
1 \\
1 \\
1\end{array}$ & $\begin{array}{l}10 \\
14 \\
12 \\
10 \\
12 \\
10 \\
13 \\
10 \\
12\end{array}$ & $\begin{array}{l}230 \\
310 \\
320 \\
310 \\
330 \\
420 \\
270 \\
290 \\
305\end{array}$ \\
\hline
\end{tabular}

Saagiandmed selle katse kohta on toodud tabelis 5 .

Uldiselt andsid kõik seemnete töötlemiseks kasutatud ained võrdlemisi lähedasi tulemusi. Kahjuks ei sobi enamik nendest ainetest suurtel pindaladel kasutamiseks. Nii ei sobi selleks porgandimahl, mis korduvalt üsna suuri saagitõuse on andnud, kuna oleks vaevalt mõeldav selle valmistamine tuhandete hektarite külviste jaoks, võttes 10 liitrit ha kohta. Raskusi tekiks ka mikroelementide soolade varumisega seemnete tööllemiseks suurte maaalade jaoks. Kuna virtsa mõju korraldatud katses jäi tunduvalt maha teiste ainete mõjust, jäävad järele linnaseleotis ja Ashby lahus. Mõlemad ained andsid katsetes umbes azotogeeniga võrdse efekti.

Tabel 5

Nelja korduse keskmised terasaagid põldkatses odraga 1951. aastal

\begin{tabular}{l|c|c|c|c}
\hline \multirow{2}{*}{ Variandid } & \multicolumn{3}{|c}{ T e r a s a a k } \\
\cline { 2 - 5 } & ts ha-lt & $\% \%$ & $\begin{array}{c}\text { kõiku- } \\
\text { mised }\end{array}$ & $\begin{array}{c}\text { saagitõus } \\
\text { kg ha kohta }\end{array}$ \\
\hline Kontroll töötlemata seemnetega & 18,52 & 100,0 & 3,8 & - \\
Kontroll suhkrulausega & 19,08 & 103,0 & 4,1 & 56 \\
Molübdeen & 21,35 & 115,3 & 6,9 & 283 \\
Mangaan & 21,20 & 114,5 & 7,6 & 268 \\
Boor & 21,02 & 113,5 & 6,8 & 250 \\
Porgandimahl & 21,12 & 114,0 & 11,3 & 260 \\
Linnaseleotis & 20,45 & 110,4 & 9,8 & 193 \\
Ashby lahus & 20,56 & 111,0 & 8,2 & 204 \\
Virts & 19,68 & 106,3 & 7,1 & 116 \\
Asotogeen (tüvi nr. 5) & 20,52 & 110,8 & 6,5 & 200 \\
& & & &
\end{tabular}

Teise perspektiivse töötlemisainena võiks kõne alla tulla Ashby lahus teatud muudatustega selle koosseisus. Ashby lahuse koosseisust võiks nähtavasti ülearustena välja jätta terve rea kemikaale, mida mullas tavaliselt alati külluses esineb (naatriumi, kaltsiumi, aluminiumi soolad jne.). Ka manniit või selle asemel tarvitatav suhkur pole laialdaseks tarvitamiseks sobivad. 
Linnaseleotise kasutamine külviseemne töötlemiseks suurte pindalade jaoks on kahtlematult võimalik ning seda on juba võrdlemisi laialdaselt rakendatud. Kahjuks on seda võtet kasutatud ka muldadel, kus saagi tõstmiseks eeldused puudusid, mille tõttu tulemused on väga ebaühtlased. O. Kiis'i ( $\left.{ }^{1}\right)$ andmetest leiame, et 1950. aastal saadi linnaseleotisega töötlemise abil enamsaaki Alatskivi sovhoosis (Kallaste rajoonis) kaera kultuuriga $4,9 \%$, (saak töötlemata seemnetega 21,16 ts ha-lt, töödeldud seemnetega $-22,20$ ts ha-lt); Peningi sovhoosis (Kose rajoonis) odra kultuuriga $17,2 \%$ (saak töötlemata seemnetega 19,23 ts ha-lt, töödeldud seemnetega 22,60 ts ha-lt); Kehra sovhoosis (Kose rajoonis) aga koguni $60,1 \%$ (saak töötlemata seemnetega 26,30 ts ha-lt, töödeldud seemnetega - 42,10 ts ha-lt). Need tulemused on täiesti mõistetavad, kui meenutame, et Alatskivi sovhoos asub hapude leetmuldade piirkonnas, kus azotobakter tavaliselt puudub, Peningi ja Kehra sovhoosid aga kamar-karbonaatsete muldade piirkonnas, kus azotobakter alati esineb.

Lähtudes sellistest kaalutlustest on tehtud katseid seemnete töötlemise jaoks eriliste segude koostamiseks, millede koostisse kuulusid kõik ained, mis võiksid olla vajalikud azotobakteri elutegevuse ergutamiseks mullas. Katsete tulemusena koostati kaks erisegu, (nende koostisainete hulk on võetud 1 hektarile külvatava teravilja või 0,5 hektarile pandava kartuli töötlemiseks):

$\mathrm{S}$ e g u nr. 1. Tärklist $350 \mathrm{~g}$, odralinnase jahu $350 \mathrm{~g}$, hernelinnase jahu $350 \mathrm{~g}$, superfosfaati $50 \mathrm{~g}$, kriiti $20 \mathrm{~g}$, ammooniummolübdaati $0,5 \mathrm{~g}$, mangaansulfaati $5 \mathrm{~g}$, booraksit $0,5 \mathrm{~g}$. Tarvitamise eel segatakse nimetatud ained 10 liitri veega.

S egu nr. 2. Tärklise ja kahesuguse linnasejahu asemel võetakse ainult $1 \mathrm{~kg}$ odralinnase jahu, kuna ülejäänud ained on samad, mis segus nr. 1.

Mõlemaid segusid kontrolliti esmakordselt 1952. aastal pōldkatsega, võrreldes nende mõju varemini kasutatud ainete mõjuga. Katsed viidi läbi Kuusiku filiaali põldudel.

Oks katse, mis oli alustatud 1951. aasta sügisel tootmistingimustes mangaaniga töödeldud talinisuga, andis $14,2 \%(3,04$ ts ha kohta) enamsaaki. Teine katse viidi läbi odraga $30 \mathrm{~m}^{2}$ suurustel katselappidel kolmes korduses. Selle katse juures teostatud mikrobioloogiline analüüs, milles määrati 5 gruppi mikroorganisme (ilma ammoonifitseerijate ja seenteta), andis eelmisest aastast mõ̃nevõrra erinevaid tulemusi (tab. 6). Erinevuste põhjuste kohta võib märkida, et seekord tehti analüüs varakevadel 12. mail, s. o. 9 päeva pärast külvamist.

Tabel 6

Keskmine mikroorganismide arv tuhandetes ühe grammi mulla kohta põldkatses odraga 1952. aastal

\begin{tabular}{l|c|c|c|c|c}
\hline Variandid & $\begin{array}{c}\text { Azoto- } \\
\text { bakter }\end{array}$ & $\begin{array}{c}\text { Clostridium } \\
\text { Pasteurianum }\end{array}$ & $\begin{array}{c}\text { Nitrifitsee- } \\
\text { rijad }\end{array}$ & $\begin{array}{c}\text { Denitrifitsee- } \\
\text { rijad }\end{array}$ & $\begin{array}{c}\text { Tselluloosi } \\
\text { laondajad }\end{array}$ \\
\hline Kontroll & 0,40 & 0,40 & 0,80 & 80 & 0,47 \\
Azotogeen & 0,50 & 0,50 & 0,50 & 50 & 5,00 \\
Segu nr. 1 & 0,55 & 0,55 & 0,55 & 55 & 5,50 \\
Segu nr. 2 & 0,48 & 0,75 & 0,75 & 75 & 7,50 \\
Molübdeen & 0,46 & 0,66 & 6,60 & 66 & 0,46 \\
Mangaan & 0,48 & 0,80 & 0,80 & 80 & 0,80
\end{tabular}

Andmetes äratab tähelepanu mikroorganismide üldine vähesus, välja arvatud denitrifitseerijad, mida on tunduvalt rohkem kui eelnevate aastate 
analüüside andmetel. Võimalik, et seda põhjustasid erakordselt madalad temperatuurid 1952. aasta mais. Nii oli analüüsi päevale eelneval 11. mail õhutemperatuur $-3,3^{\circ} \mathrm{C}, 9$. mail aga $-4,9^{\circ} \mathrm{C}$. Kuigi sademete hulk oli suurem kui eelmistel aastatel, pidurdasid madalad temperatuurid mulla mikroorganismide arengut.

1952. aastal rajati pōldkatse odraga jälle kahel lämmastiku foonil: $150 \mathrm{~kg} / \mathrm{ha}$ ammooniumsalpeetriga ja ilma mineraal-lämmastikväetiseta. Katseandmed on toodud tahelis 7.

Tabel 7

Saagiandmed orda põldkatses seemnete töötlemisel mitmesuguste ainetega 1952. aastal ENSV TA Taimekasvatuse Instituudi Kuusiku filiaalis

\begin{tabular}{|c|c|c|c|c|}
\hline \multirow{2}{*}{ Variandid } & \multicolumn{3}{|c|}{ Teras a a k } & \multirow{2}{*}{$\begin{array}{l}\text { Saagitõus } \\
\mathrm{kg} \text { ha-1t }\end{array}$} \\
\hline & ts ha-lt & $\% \%$ & kōikumised & \\
\hline & \multicolumn{3}{|c|}{$\begin{array}{c}\text { Mineraa } 1-1 \text { àm mastik- } \\
\text { väetiseta }\end{array}$} & \multirow{3}{*}{$\begin{aligned} & - \\
+ & 341,9 \\
+ & 264,2 \\
+ & 239,8 \\
+ & 508,4 \\
+ & 390,7\end{aligned}$} \\
\hline $\begin{array}{l}\text { Kontroll } \\
\text { Azotogeen } \\
\text { Segu nr. } 1 \\
\text { Segu nr. } 2 \\
\text { Mangaan } \\
\text { Molübdeen }\end{array}$ & $\begin{array}{l}22,200 \\
25,619 \\
24,842 \\
24,598 \\
27,284 \\
26,107\end{array}$ & $\begin{array}{l}100,0 \\
115,4 \\
111,9 \\
110,8 \\
122,9 \\
117,6\end{array}$ & $\begin{array}{l}2,7 \\
3,0 \\
3,5 \\
7,4 \\
2,8 \\
7,7\end{array}$ & \\
\hline & \multicolumn{3}{|c|}{$\begin{array}{c}\text { Minera a } 1-1 \text { ä m mastik- } \\
\text { väetiseg a }\end{array}$} & \\
\hline $\begin{array}{l}\text { Kontroll } \\
\text { Azotogeen } \\
\text { Segu nr. } 1 \\
\text { Segu nr. } 2 \\
\text { Mangaan } \\
\text { Molübdeen }\end{array}$ & $\begin{array}{l}37,792 \\
36,188 \\
37,472 \\
38,676 \\
38,056 \\
37,042\end{array}$ & $\begin{array}{r}100,0 \\
95,8 \\
99,2 \\
102,3 \\
100,7 \\
98,0\end{array}$ & $\begin{array}{l}3,9 \\
3,1 \\
1,1 \\
4,4 \\
3,3 \\
4,3\end{array}$ & $\begin{array}{r}-\overline{160,4} \\
-\quad 32,0 \\
+\quad 88,4 \\
+\quad 26,4 \\
-\quad 74,4\end{array}$ \\
\hline
\end{tabular}

1952. aasta saagiandmetes puutuvad silma kõigepealt eelnevatest aastatest tunduvalt kõrgemad saagid üldse: ka ilma lämmastikväetisteta üle 22 tsentneri ha kohta kontrollalal. See viitab paremale agrofoonile, millisel nii azotogeen kui ka seemnete töötlemine pidid andma paremaid tulemusi. Teiselt poolt aga vähendasid ebasoodsad meteoroloogilised tingimused (kevadised madalad temperatuurid) seemnete töötlemise efektiivsust, millega võib seletada seda, et saagitõusud siiski ei küündinud 1949. aasta tasemeni.

Teine huvitav moment esitatud andmetes on peaaegu igasuguse efekti puudumine seemnete töötlemisel kõrge lämmastikväetise foonil, kus saakide kõikumised jäävad täiesti katsevigade piiridesse, lämmastikuta foonil aga esinevad $11-23$ protsendilised enamsaagid.

Kõigi ENSV TA Taimekasvatuse Instituudi Kuusiku filiaalis korraldatud põldkatsete kohta teraviljade seemnete külvieelse töötlemisega ajavahemikul 1947. kuni 1953. aastani on saadud tab. 8 toodud keskmised tulemused. Selles kokkuvõttes on arvestatud eraldi andmed mineraal-lämmastikväetiste foonil (150 kg ammooniumsalpeetrit ha kohta) ja ilma mineraal-lämmastikväetiseta. 
Tabel 8

Keskmised saagitõusud teravilja põldkatsetes seemnetega külvieelse töötlemise tagajärjel ENSV TA Taimekasvatuse Instituudi Kuusiku filiaalis aastail 1947-1953

\begin{tabular}{|c|c|c|c|c|c|c|}
\hline \multirow[b]{2}{*}{$\begin{array}{l}\text { Stimuleeriv } \\
\text { aine }\end{array}$} & \multicolumn{2}{|c|}{$\begin{array}{c}\text { Korraldatud } \\
\text { põldkatsete arv }\end{array}$} & \multicolumn{2}{|c|}{$\begin{array}{c}\text { Keskmine terasaagi- } \\
\text { tôus } \%\end{array}$} & \multicolumn{2}{|c|}{$\begin{array}{l}\text { Esinenud kōige kōr- } \\
\text { gemad saagitōusud }\end{array}$} \\
\hline & $\begin{array}{l}\text { Mineraal- } \\
\text { lämmas- } \\
\text { tikuta } \\
\text { foonil }\end{array}$ & $\begin{array}{c}\text { Mineraal- } \\
\text { låmmas- } \\
\text { tiku } \\
\text { foonil }\end{array}$ & $\begin{array}{l}\text { Mineraal- } \\
\text { lämmas- } \\
\text { tikuta } \\
\text { foonil }\end{array}$ & $\begin{array}{c}\text { Mineraal- } \\
\text { limmas- } \\
\text { tiku } \\
\text { foonil }\end{array}$ & $\begin{array}{c}\text { Mineraal- } \\
\text { lämmas- } \\
\text { tikuta } \\
\text { foonil }\end{array}$ & $\begin{array}{l}\text { Mineraal- } \\
\text { lămmastiku } \\
\text { foonil }\end{array}$ \\
\hline $\begin{array}{l}\text { Mangaan } \\
\text { Molübdeen } \\
\text { Boor } \\
\text { Vanaadium } \\
\text { Volfram } \\
\text { Porgandimahl } \\
\text { Linnaseleotis } \\
\text { Ashby lahus } \\
\text { Segu nr. } 1 \\
\text { Segu nr. } 2 \\
\text { Virts }\end{array}$ & $\begin{array}{l}9 \\
8 \\
6 \\
4 \\
3 \\
5 \\
2 \\
1 \\
1 \\
1 \\
1 \\
\end{array}$ & $\begin{array}{r}4 \\
4 \\
3 \\
3 \\
2 \\
3 \\
- \\
- \\
- \\
\end{array}$ & $\begin{array}{r}15,1 \\
14,4 \\
13,1 \\
5,3 \\
4,5 \\
10,8 \\
9,7 \\
11,0 \\
11,9 \\
10,8 \\
6,3 \\
\end{array}$ & $\begin{array}{l}2,5 \\
4,3 \\
4,1 \\
2,9 \\
3,5 \\
0,4 \\
- \\
- \\
- \\
- \\
\end{array}$ & $\begin{array}{r}28,9 \\
23,1 \\
28,3 \\
9,2 \\
7,5 \\
18,2 \\
10,4 \\
11,0 \\
11,9 \\
10,8 \\
6,3 \\
\end{array}$ & $\begin{array}{l}5,9 \\
9,0 \\
5,9 \\
3,5 \\
3,8 \\
2,5 \\
- \\
- \\
- \\
- \\
\end{array}$ \\
\hline $\mathrm{Kokku}$ & 41 & 19 & & & & \\
\hline $\begin{array}{l}\text { Kỗigi katsete } \\
\text { keskmine }\end{array}$ & - & - & 11,7 & 3,0 & 15,1 & 5,1 \\
\hline
\end{tabular}

Esitatud kokkuvõte näitab, et tulemused seemnete töötlemisest lämmastikväetiseta foonil on võrdlemisi lähedased tulemustele azotogeeni tarvitamisel. Kui vaadelda saagiandmeid üksikute aastate viisi, siis selgub, et seemnete töötlemine andis paremaid tulemusi samadel aastatel kui azotogeeni tarvitaminegi, nimelt aastatel, mil sademete hulk ja keskmine mulla temperatuur oli kõrgem (1949. a.). Kõigi katsete puhul saadi paremaid tulemusi kõrgema agrofooni juures - paremini haritud ja väetatud muldadel. Kokkuvõttes äratab tähelepanu vahe saagitõusudes mineraal-lämmastikväetiste foonil, kus õhulämmastikku fikseerivate mikroorganismide tegevus -mullas oli välja lülitatud, ning ilma lämmastikväetisteta foonil.

Siin esineb siiski oluline vahe üksikute ainete vahel, mida seemnete töötlemiseks kasutati. Kõik kasutatud mikroelemendid andsid siiski ka kõrgel $\mathrm{N}$-foonil mõninga enamsaagi, üksikutel juhtudel isegi kuni $9 \%$. Mõne mikroelemendi puhul polnud saagitõus kahel erineval lämmastiku foonil kuigi palju erinev, näiteks oli erinevus volframi kasutamisel, kus efekt oli üldse väga väike, ainult $1 \%$ ! Seemnete töötlemisel orgaaniliste ainetega aga puudus selle võtte saaketõstev toime kõrgel lämmastikväetiste foonil peaaegu täiesti (katsed porgandimahlaga).

Kui meenutame veel mikrobioloogilise analüüsi andmeid, mis kõigil juhtudel näitasid suuremat mulla mikroorganismide, eriti azotobakteri hulka nendel variantidel, mis olid külvatud töödeldud seemnetega, võib küllaldaselt põhjendatuks lugeda teoreetilist seisukohta, et seemnete mikroelementidega või orgaaniliste ainetega külvieelse töötlemise efekt oleneb p e a m i selt selle võtte mõjust mulla mikrobioloogilistele protsessidele, eelkõige azotobakteri arengule, algul mulda külvatud seemne lähemas ümbruses, hiljem seemnest moodustunud taime juurekava ümbruses.

Sellelt seisukohalt võib kerkida küsimus, mispärast kõige suurema efekti andis just mangaan, mida, kui peetaksegi azotobakteri elutegevust stimuleerivaks aineks, siis ikkagi teisejärguliseks, vähem efektiivseks kui molübdeen. 
Võib arvata, et iga töötlemiseks kasutatava mikroelemendi efektiivsus nii azotobakteri, kui ka kõrgema taime elutegevusele oleneb kohaliku mullastiku tingimustest. Mikroelement, mis teatud mullastiku tingimustes osutub väga efektiivseks, võib teistsugustes tingimustes jääda mõjuta või mõjuda isegi kahjulikult.

Esitatud andmed viitavad kaudselt sellele, et muldades, milledel need katsed korraldati, on mikroelementidest kõige defitsiitsem mangaan. Katsete algul ei õnnestunud vastavaid mullaanalüüse mikroelementide sisalduse kohta teostada. Alles 1952. aastal võeti esimesed mullaproovid Kuusiku filiaali põldudelt, mida analüüsides konstateeriti, et üldiselt Kuusiku filiaali mullad on mangaanivaesed (sisaldades seda ainult 0,0014 kuni $0,024 \%$, keskmine mangaanisisaldus Eesti NSV muldades on aga $0,04-0,05 \%)$. Teiste katsetatud mikroelementide sisalduse kohta Kuusiku muldades puuduvad seni andmed.

Konstateerides mangaani erilist mõju Kuusiku filiaalis teostatud katsetes, võiks teistel muldadel, kus ei esine ühegi mikroelemendi puudust või liiga suurt sisaldust, seemnete töötlemisainena esikohal olla molübdeen.

Kõigi esitatud katseandmete põhjal tuleb teha alljärgnevad järeldused.

1. Kuna muldades, mis on azotobakterile vastuvõetavad, esineb alati looduslik azotobakter, välja arvatud vaid juhud, kus mullastiku tingimusi alles äsja on muudetud, võib azotobakteri väetispreparaatide asemel edukalt kasutada seemnete külvieelset töötlemist ainetega, mis soodustavad azotobakteri arengut ja elutegevust. Sellised ained võimaldavad azotobakteri ja mõne teise mulla mikroorganismi kogunemist taimekasvu kõige varasemas staadiumis seemnete lähemasse ümbrusse, kust need levivad juurekava moodustumisel kogu juurekava ulatuses, millega saavutatakse taimede parem varustamine mikroorganismide poolt seotava õhulämmastikuga.

2. Seemnete külvieelne töötlemine azotobakteri arengut ja tegevust soodustavate ainetega vổib omada mōningaid paremusi võrreldes azotobakteri väetispreparaatide tarvitamisega, eriti talivilja kultuuride juures, kus kunstlikult mulda viidud azotobakteri rakukesed talve kestel võivad hävineda, keemilised ained aga säilivad järgmise kevadeni. Suviviljade kultuuride puhul omab praktilist tähtsust vaid lihtsam käsitamine, kuna töötlemiseks kasutatavaid aineid ei ole tarvis hoida külmumiste ja ülessulatamiste eest, päikese kiirte eest jne.

3. Puhtpraktilise tâhtsuse kõrval omavad esitatud katseandmed ka teoreetilist tähtsust, näidates, et vastavate uurimuste läbiviimisel ei tohi unustada mulla mikroorganismide osatähtsust, kuna näiteks seemnete külvieelsel töötlemisel väga mitmesuguste ainetega saavad mõjutatud mitte ainult taime füsioloogilised protsessid, vaid väga suurel määral ka mulla mikrobioloogilised protsessid. Viimaste mõju viljasaakide kujunemisele võib aga osutuda isegi suuremaks kui seemnete töötlemise vahetu mõju taime füsioloogilistele protsessidele. 
1. O. K i is, Seemnete külvieelse töötlemise tulemustest sovhoosides. „Sotsialistlik Põllumajandus", 1952, nr. 2, 1k. 150.

2. N. Mokin, Külvieelne seemnete rikastamine. „Rahva Hääl”, nr. 91 (2209), 15. apr. 1950. a.

3. P. Rahno, Mullabakterite tegevuse soodustamine seemnete külvieelse töötlemise teel. „Sotsialistlik Põllumajandus”, 1951. nr. 11, lk. 828.

4. П. А. В ла с юк и М. М. Шкв а р ук, Збільшения врожаю зернових хлібів піл вливом предпосівно обробки солями марганець і цинксульфатів. Бот. журнал АН УССР 3 , № 3-4, 1946, стр. 113.

5. Д. И. Гобелев, Влияние растворов электролитов при яровизации яровых пшениц на их развитие и урожай. Уч. зап. Рязанского Гос. Пед. Ин-та, Рязань, 1949, стр. 97-109.

6. С. А. Гликман, Современное состояние вопроса о стимулировании семян. Тр. по прикл. бот., ген. и сел., 23, 1929-1930, вын. 2.

7. С. И. Желагов, Стимулирование семян по методу проф. М. Попова. Научноагр. журнал., 1927, № 2, стр. 75 .

8. А. 3. Л а м бин, Микроэлементы как фактор урожайности. Тр. Омского с. х. Ин-та, 1938, № 3.

9. А. 3. Л ам бин, Влияние допосевной обработки семян растворами разных концентраций микроэлементов на урожай яровой пшеницы. Омский с. $\mathrm{x}$. ин-т, Тезисы и авторефераты, 1947 , стр. 42,1948 , стр. $44-45$.

10. С. И. М а туашвили, Микроэлементы как фактор, влияющий на физиологические и морфологические свойства микроба Azotobacter chroococcum. Диссертационная работа, 1940.

11. С. И. М атуашвили, О влиянии бора й молибдена на морфологические и цитологические свойства Azotobacter chrooćoccum. Микробиология, 1947, т. 16, вып, 1, стр. 19-31.

12. К. А. Миротворски й и Г. $М$. Г Гигорян, Влияние солевого режима и микроэлементов на развитие бактерий в почве. Изв. Туркменского фил. АН CССР, 1945, № 1, стр. 42.

13. Н. Н. Мокин, О повышении оплаты удобрения хлопчатника мегодом стимуляцић, Удобрения и урожай, 1931 , № $11-12$, стр. 1041.

14. Н. Н. Мокин, Особенности биохимических процессов при лрорастании обогащенных семян, Достижения наукя и передового опыта в с. х., 1953, № 9, стр. $85-87$.

15. П. Р ахно, Влияние предпосевной обработки семян растворами солей микроэлементов на урожайность зерновых культур, Реф. докл. на конф. по микроэлем., изд. АН СССР, 1950, стр. 94.

16. М. В. Фед оров, Микробнология, 4 изд. Сельхозгиз, Москва, 1949.

17. М. В. Федоров, Биологическая фиксация азота атмосферы, Сельхозгиз, Москва, 1948, 1952.

18. М. Я. Ш кольн и к, Значение микроэлементов в жизни растений и в земледелии, Изд. АН СССР, М.-Л., 1950.

19. H. B ortels, Molybdän als Katalysator bei der biologischen Stickstofíbindung. Arch. Mikrob., 1930, Bd. 1, H. 3, S. 285.

20. H. Bortels, Untersuchungen über die Bedeutung von Molybdän, Vanadium, Wolfram und andere Erdaschenstoffe für stickstoffbindende und andere Mikroorganismen. Zentralbl. f. Bakt. (Abt. 2), 1936, Bd. 95, S. 193.

21. H. Bortels, Ober die Wirkung von Molybdän- und Vanadiumdüngungen auf Azotobacter-Zahl und Stickstoffbindung im Erde. Arch. Mikrobiol., 1937, № 8.

22. H. B ortels, Kurze Notiz über die Katalyse der biologischen Stickstoffbindung. Zentrbl. f. Bakt., 1938, Bd. 27, S. 476.

23. D. Burk a. C. Horner, The Production of Ammonia by Azotobacter and Its Relation to the Mechanism of Nitrogen. Fixation. Trans. A. Third Intern Soil Sci. Congr., Vol. 1, 1935, p. 148.

24. G. G a s s n e r, Der gegenwärtige Stand der Stimultationsfrage. Ber. D. Bot. Gesellsch, 1926, № 44, S. 341.

25. F. Herzniger, Beiträge zum Wirkungskreislauf des Bors. Bodenkunde u. Pflanzenernährung, 1940, № 46 (3/4), S. 141.

26. M. P o p of f, Die Zellstimulation. Berlin, 1931.

27. M. P o p of f u. W. Gle is be r g, „Zellstimulationforschungen”, 1924-1926.

28. C. B. V a n-Nie I, A Note on the Apparent Absence of Azotobacter in Soils. Arch. Mikrobiol., 1935, Vol. 6. No 3, p. 215. 


\title{
УСИЛЕНИЕ РАЗВИТИЯ ПОЛЕЗНОЙ ПОЧВЕННОЙ МИКРОФЛОРЫ ПРИ ПОМОЩИ ОБРАБОТКИ СЕМЯН МИКРОЭЛЕМЕНТАМИ И ДРУГИМИ СТИМУЛИРУЮЩИМИ ВЕЩЕСТВАМИ
}

\author{
П. Х. РАХНО, \\ кандидат биологических наук
}

Резюме

Плодородие почвы неразрывно связано с деятельностью почвенных микроорганизмов и поэтому для повышения плодородия почвы весьма важно активно воздействовать на почвенную микрофлору. Помимо общих агроприемов, для этого используются и некоторые специальные приемы, из которых наиболее широко применяется внесение бактериальных удобрений.

Широкое применение получили препараты азотусвояющих микроорганизмов, особенно азотоген (почвенный препарат) или азотобактерин (чистые культуры азотобактера).

Препараты азотобактера дают значительные повышения урожаев только при высоком агротехническом уровне и только на почвах, отвечающих всем требованиям азотобактера. Но в таких почвах почти всегда имеется свой, природный, азотобактер, и эффективность внесенного препарата азотобактера зависит.в этом случае от периода размножения природного азотобактера и от времени внесения искусственного препарата.

Поскольку применение препаратов азотобактера обычно дает эффект только на таких почвах, в которых содержится природный азотобактер, возникает вопрос, нельзя ли вместо внесения в такую почву клеток азотобактера, выделенных из других почв, вносить сюда какөе-либо вещество, стимулирующее развитие азотобактера. Такое вещество, внесенное в почву на семенах, способствовало бы, как и препараты азотобактера, привлечению природного азотобактера из окружающей почвы на семена. В этом случае мы, вместо того, чтобы выделять из почвы азотобактер на лабораторных средах и вносить его потом снова в почву, притом, может быть, весьма отдаленную от места его первоначального выделения, будем иметь возможность интенсифицировать его развитие на самих семенах, в условиях его постоянного обитания.

Чтобы выделить азотобактер из окружающей почвы и содействовать развитию его на посеянных семенах полевых растений, необходимо добиться создания особенно благоприятных условий для его жизнедеятельности в непосредственной близости от семян, а в дальнейшем и в ризосфере растения. Такую задачу можно решить путем предпосевной обработки семян веществами, стимулирующими жизнедеятельность азотобактера.

Предпосевной обработкой семян различными веществами физиологІ растений занимались уже давно. Во многих случаях обработка дала повышение урожаев, но были и случаи, когда не удалось установить никакого эффекта от обработки семян. Подобные же разнородные и непостоянные результаты получаются и при применении препаратов азотобактера без учета конкретных почвенных условий. Если предположить, что обработка семян оказывает влияние только на физиологические процессы в самом растении, то такое непостоянство в результатах обработки семян остается совершенно непонятным. Если же считать, что на повышение урожаев оказывает влияние не только та часть применяемых для обработки семян веществ, которая всасывается семенами, но и та, количест- 
венно бо́льшая часть их, которая после обработки остается на оболочках семян, попадает вместе с семенами в почву и здесь стимулирует развитие полезных почвенных микроорганизмов, то ясно, что результаты обработки должны- быть различны, в зависимости от состава почвенной микрофлоры в различных почвах.

Для выяснения значения микробиологического фактора на опытных полях филиала Куузику Института растениеводства Академии наук ЭССР в 1946-1952 гг. были проведены соответствуюшие опыты. Почва на опытных участках была нейтральная дерново-карбонатная, которая содержала природный азотобактер в довольно большом количестве. По всем вариантам опыта была дана одинаковая норма фосфорно-калийных удобрений, обычно 200 кг суперфосфата и 100 кг $40 \%$ калийной соли на га. Органические удобрения при опытах с яровыми зерновыми культурами не применялись. Азотные минеральные удобрения применялись только в отдельных опытах; в этом случае в одной половине всех вариантов мы давали предельно высокую норму минерального азота, обычно 150 кг аммиачной селитры на га, а другую половину оставляли без минерального азота. При этом предполагалось, что если обработка семян влияет в основном на физиологические процессы растения, то повышение урожаев должно быть приблизительно одинаковым как в вариантах опытов с усиленным азотным питанием, так и в вариантах без минерального азота. Если же эффект обработки семян обусловлен главным образом влиянием на деятельность азотфиксирующих микроорганизмов почвы, то повышение урожаев-должно быть значительно больше в тех вариантах опытов, в которых минеральные азотные удобрения не применялись.

На деле так и получалось: во всех опытах повышение урожаев было значительно больше на безазотистом фоне. Среднее повышение урожаев от обработки семян на безазотистом фоне, по данным 41 опыта, равнялось $11,7 \%$, а на фоне минерального азота, по данным 19 опытов, только $3,0 \%$. Самые высокие повышения урожаев от обработки семян некоторыми микроэлементами на безазотистом фоне приближались к $30 \%$, а на фоне минерального азота только в одном случае повышение урожая достигало $9,0 \%$.

Микробиологические анализы показали значительное увеличение количества полезных почвенных микроорганизмов, особенно азотобактера, на корнях и в ризосфере растений, а также в почве, окружающей корневую систему растений, семена которых проходили обработку. В опытах лучшие результаты были получены от применения сернокислого марганца, затем буры и аммониевокислого молибдена. Все применяемые для обработки органические вещества дали приблизительно равное повышение урожаев (от 10 до $12 \%$ ).

Повышения урожаев вследствие обработки семян сходны с повышениями, полученными от применения препаратов азотобактера, притом лучшие результаты получены в те же годы, когда и азотоген дал наибольшие повышения урожаев, а именно в такие годы, когда количество осадков и средняя температура почвы в начале вегетационного периода были выше (1949 г.).

На основании полученных опытных данных можно сделать следующие выводы.

1. Так как в почвах, которые отвечают требованиям азотобактера, почти всегда имеется природный азотобактер, то на таких почвах, вместо препаратов азотобактера, можно успешно применять предпосевную обработку семян веществами, стимулирующим развитие и жизнедеятельность азотобактера. Такие вещества будут способствовать успешному развитию 
азотобактера и некоторых других почвенных микроорганизмов около семян в самый ранний период вегетации. По мере образования корневой системы они распространяются по ней, что обеспечивает усиленное питание растения азотом.

2. Обработка семян веществами, стимулирующими развитие и жизнедеятельность азотобактера, может иметь некоторые преимущества в сравнении с применением препаратов азотобактера, особенно при озимых культурах, ибо внесенные в почву клетки азотобактера за зиму могут погибнуть, тогда как химические вещества сохраняются до следующего вегетационного периода. При яровых культурах некоторое практическое значение имеет только простота в обращении с этими веществами при транспорте, хранении и обработке.

3. Кроме чисто практического значения, представленные опытные данные имеют также теоретическое значение, показывая, что при проведении соответствующих опытов нельзя забывать о роли почвенных микроорганизмов. Обработкой семян оказывается воздействие не только на физиологические процессы самого высшего растения, но в значительної мере и на микробиологические процессы почвы. С точки зрения повышения урожаев этот последний эффект может быть дает больше, чем тот, который достигается воздействием на физиологические процессы, происходящие в самих растениях.

Ннститут растениеводства Академии наук Эстонской ССР
Поступила в редакцию 3 XI 1953 